\title{
SEGREGATION IN POST-CIVIL RIGHTS AMERICA
}

\section{Stalled Integration or End of the Segregated Century?}

\author{
Jacob S. Rugh \\ Department of Sociology, Brigham Young University \\ Douglas S. Massey \\ Office of Population Research, Princeton University
}

\begin{abstract}
In this paper we adjudicate between competing claims of persisting segregation and rapid integration by analyzing trends in residential dissimilarity and spatial isolation for African Americans, Hispanics, and Asians living in 287 consistently defined metropolitan areas from 1970 to 2010. On average, Black segregation and isolation have fallen steadily but still remain very high in many areas, particularly those areas historically characterized by hypersegregation. In contrast, Hispanic segregation has increased slightly but Hispanic isolation has risen substantially owing to rapid population growth. Asian segregation has changed little and remains moderate, and although Asian isolation has increased it remains at low levels compared with other groups. Whites remain quite isolated from all three minority groups in metropolitan America, despite rising diversity and some shifts toward integration from the minority viewpoint.

Multivariate analyses reveal that minority segregation and spatial isolation are actively produced in some areas by restrictive density zoning regimes, large and/or rising minority percentages, lagging minority socioeconomic status, and active expressions of anti-Black and anti-Latino sentiment, especially in large metropolitan areas. Areas displaying these characteristics are either integrating very slowly (in the case of Blacks) or becoming more segregated (in the case of Hispanics), whereas those lacking these attributes are clearly moving toward integration, often quite rapidly.
\end{abstract}

Keywords: Segregation, African Americans, Latinos, Discrimination, Land Use Zoning

\section{INTRODUCTION}

Analyses of racial and ethnic segregation in the United States indicated three basic trends at the end of the twentieth century: (1) slow but steady declines in the degree of Black-White segregation (measured by the index of dissimilarity) with parallel declines in Black spatial isolation (measured by the $\mathrm{P}^{*}$ index); (2) the continued residential 
segregation and spatial isolation of Asians at low to moderate levels with no significant trend upward or downward; and (3) steady Hispanic segregation at moderate to high levels combined with rising levels of Hispanic spatial isolation (Iceland 2009; Logan et al., 2004; Massey et al., 2009). Preliminary work based on the 2010 census has yielded widely discrepant reports on America's progress toward integration. Whereas Logan and Stults (2011) see the persistence of segregation and argue that "the pace of integration has slowed to a standstill," Glaeser and Vigdor (2011) proclaim "the end of the segregated century."

The past forty years have witnessed a plethora of powerful demographic, economic, and social shifts that have transformed race relations in the United States to produce a more complicated residential configuration in American cities. Demographically, the nation has been reshaped by mass immigration from Asia and Latin America, changing the paradigmatic urban structure from the "chocolate city and vanilla suburbs" of the 1960s (Farley et al., 1978) to the "prismatic metropolis" of the new millennium (Zubrinsky and Bobo, 1996). In economic terms, inequalities of income and wealth have risen to record levels (Keister 2000; Piketty and Saez, 2007; Wolff 2010), class segregation has increased (Massey and Fischer, 2003; Reardon and Bischoff, 2011), and the socioeconomic gap between Whites and minorities has widened, even as many minority members have moved into the middle class (Massey 2007).

In the social realm, attitudes towards African Americans have shifted so that Whites no longer support segregation and discrimination as matters of principle, though many continue to harbor negative racial stereotypes, display limited tolerance of racial mixing, and offer little support for any form of civil rights enforcement (Bobo 2004; Bobo and Charles, 2009; Massey 2011; Schuman et al., 1998). Latinos, meanwhile, have increasingly been demonized as a threat to American society and depicted in harsh, racially coded terms (Chavez 2001, 2008; Massey 2009; Massey and Pren, 2012a, b; Massey and Sanchez, 2010; Santa Ana 2002). With respect to both groups, unconscious racism and prejudice also appear to be prevalent American social cognition (Banaji 2001; Fiske et al., 2009; Lee and Fiske, 2006; Quillian 2006) and play at least some role in shaping behavior (Bargh 2004; Ziegert and Hanges, 2005).

Public policies enacted during the Civil Rights era appear largely to have ended overt racial discrimination in real estate and lending markets. Discrimination in housing was prohibited by the 1968 Fair Housing Act and discrimination in mortgage lending was banned by the 1974 Equal Credit Opportunity Act and the 1977 Community Reinvestment Act. As a result, minorities are no longer openly denied access to homes and credit, though audit studies reveal that traditional discriminatory practices continue surreptitiously (Charles 2003; Ross and Turner, 2004; Squires 1994; Turner et al., 2002). In addition, new and more subtle forms of discrimination have been invented (Massey 2005), including linguistic profiling (Fischer and Massey, 2004; Massey and Lundy, 2001; Purnell et al., 1999; Squires and Chadwick, 2006), predatory lending (Lord 2004; Renuart 2004; Squires 2004), and reverse redlining (Brescia 2009; Friedman and Squires, 2005; Rugh and Massey, 2010; Smith and DeLair, 1999; Turner et al., 2002; Williams et al., 2005).

In recent decades, density zoning has emerged as a powerful force promoting racial segregation. Limits on the density of residential construction in predominantly White communities drive up the cost of housing to make it unaffordable to low income, minority households (Glaeser et al., 2005; Pendall 2000). As result, the more restrictive the density zoning regime (the stricter the limits on residential density), the higher the level of racial segregation and the less the shift toward integration over time (Rothwell2011; Rothwell and Massey, 2009). Unsurprisingly, restrictive density zoning has also been linked to higher levels of income segregation (Rothwell and Massey, 2010), and instrumental variable regressions suggest both relationships are not only strong, but causal. 
In sum, whereas certain causes of segregation may have faded, new ones have appeared and the effects on levels and trends in residential segregation in the United States today are unclear. In this paper we seek to shed light on the true nature of the current situation by undertaking a systematic analysis of trends in the residential segregation and spatial isolation for Blacks, Whites, Hispanics, and Asians using a balanced panel of 287 metropolitan areas with consistently defined metropolitan boundaries from 1970 through 2010. After considering trends in segregation and spatial isolation, we specify and estimate a comprehensive explanatory model to reveal the underlying causes of residential segregation for Blacks and Hispanics in many quarters of the United States. In doing so we seek to identify the metropolitan circumstances in which segregation continues to be actively produced, and those in which shifts toward desegregation are facilitated.

\section{DATA AND METHODS}

Our principal data source is the Decennial Census of Housing and Population for 1970, 1980, 1990, 2000, and 2010 and the 2008-2010 American Community Survey. We extracted data on measures of residential segregation and spatial isolation for 1980-2010 from Logan and Stults (2011) for all metropolitan areas and divisions (hereafter MSAs) in the United States as defined in 2009. For 1970 we used data from the professional version of Social Explorer ${ }^{1}$ at the census tract level to compute segregation and isolation indices for MSAs as defined in 2009. Our dataset consists of a balanced panel of 287 consistently defined MSAs for which we were able to compute segregation indices for 1970-2010. The MSAs included in our analysis are listed in Appendix A.

Here we focus on two of segregation's five constituent dimensions: unevenness and isolation (Massey and Denton, 1988a). We measure unevenness using the wellknown index of dissimilarity, which captures the degree to which the residential distribution of any two groups departs from the ideal of evenness. In an even distribution, each neighborhood has the same proportion of minority and majority members as the metropolitan area as a whole. Our indicator of neighborhood is the census tract and we consider three minority groups-non-Hispanic Blacks, non-Hispanic Asians, and Hispanics and compare their residential distribution to that of non-Hispanic Whites. Under these circumstances, the index of dissimilarity states the relative percentage of minority group members and non-Hispanic Whites who would have to exchange tracts to achieve an even residential distribution.

We measure a group's spatial isolation using the $\mathrm{P}^{*}$ index, which gives the minority percentage within the neighborhood of the average minority member. The Black isolation index, for example, gives the percentage Black in the neighborhood of the average African American residing in a particular metropolitan area. Whereas the dissimilarity index is invariant with respect to the minority-majority composition of a metropolitan area, the isolation index directly depends on the relative number of minority versus majority group members.

In order to consider the determinants of residential segregation and spatial isolation we assembled data on a variety of variables that prior studies have shown to be relevant in shaping residential outcomes in U.S. metropolitan areas, which are listed in Table 1. Until now investigators have been unable to measure variation in the extent of racial-ethnic prejudice across metropolitan areas, owing mainly to the cost of developing reliable survey estimates from probability samples of hundreds of different areas but also to the reluctance of respondents to admit to having prejudicial sentiments. 
Table 1. Independent Variables Used to Predict Segregation Outcomes for Blacks, Hispanics, and Asians

\begin{tabular}{|c|c|}
\hline Variable & Definition \\
\hline \multicolumn{2}{|l|}{ Racial Prejudice } \\
\hline Anti-Black Index & $\begin{array}{l}\text { Relative Frequency of Google Searches for word } \\
\text { "Nigger" }\end{array}$ \\
\hline Anti-Latino Index & Relative Frequency of Google Searches for "Illegal Alien" \\
\hline \multicolumn{2}{|l|}{ Zoning Regime } \\
\hline Zoning Permissiveness & $\begin{array}{l}\text { Instrumental Variable Derived from Rothwell and } \\
\text { Massey (2009) }\end{array}$ \\
\hline \multicolumn{2}{|l|}{ Minority Composition } \\
\hline Percent Black & Percentage Black in MSA \\
\hline Percent Hispanic & Percentage Hispanic in MSA \\
\hline Percent Asian & Percentage Asian in MSA \\
\hline \multicolumn{2}{|l|}{ Socioeconomic Status } \\
\hline Ratio Minority/White HH Income & Ratio of Minority-to White Household Income \\
\hline $\begin{array}{l}\text { Ratio Minority/White College } \\
\text { Grads }\end{array}$ & $\begin{array}{l}\text { Ratio of Minority-to White Percentage College } \\
\text { Graduate }\end{array}$ \\
\hline Percent Homeowner & Percentage of Homeowners in MSA \\
\hline \multicolumn{2}{|l|}{ Population } \\
\hline Log MSA Population & Log of Total MSA Population \\
\hline Percent Foreign Born & Percentage Foreign Born in MSA \\
\hline Percent Female Headed & Percentage of Female Headed Families in MSA \\
\hline Percent Aged 65+ & Percentage of MSA Population Aged 65 or Greater \\
\hline \multicolumn{2}{|l|}{ Industrial Organization } \\
\hline Percent Manufacturing & Percentage of Workers in Manufacturing \\
\hline Percent FIRE & $\begin{array}{l}\text { Percentage of Workers in Finance, Insurance, \& Real } \\
\text { Estate }\end{array}$ \\
\hline Percent Education & Percentage of Workers in Education \\
\hline Log Military Population & $\begin{array}{l}\text { Log of Persons Housed in Military Quarters per } \\
100,000 \text { in MSA }\end{array}$ \\
\hline Percent Unionized & $\begin{array}{l}\text { Percentage of Workers in Union (for State in 1980; } \\
2010 \text { for MSA) }\end{array}$ \\
\hline Patents per Capita & $\begin{array}{l}\text { Patents per 100,000 Persons (for State in 1980; for } \\
\text { MSA in 2010) }\end{array}$ \\
\hline \multicolumn{2}{|l|}{ Urbanism } \\
\hline Percent Urban & Percent Urban in MSA \\
\hline Violent Crime Rate & Violent Crimes per 1,000 Persons \\
\hline Median Year Housing & Median Year MSA Housing was Built \\
\hline \multicolumn{2}{|l|}{ Geography } \\
\hline Northeast & Northeastern Census Region \\
\hline South & Southern Census Region \\
\hline West & Western Census Region \\
\hline Coastal & MSA Borders Atlantic, Pacific, or Gulf of Mexico \\
\hline Border & Located in State Bordering Mexico \\
\hline
\end{tabular}


Google Trends, however, offers new opportunities to assess topics that were previously difficult for survey researchers to tackle (Stephens-Davidowitz 2013). For example, the most extreme expression of anti-Black sentiment and the harshest epithet one can apply to an African American is the word "nigger" and when we entered variations on this term into Google Trends we found it to be the subject of a large volume of internet searches that yielded a robust and quite variable distribution of frequencies across metropolitan areas since 2004.

Stephens-Davidowitz (2013) performed a similar operation using Google Trends and found that the resulting index correlated strongly with other known measures of racial prejudice at the aggregate level; the index strongly predicted voter turnout for Obama across market areas in the 2008 presidential election. Whereas he used market areas, we employed metropolitan areas, which are smaller, and found that in some the volume of searches was too small to support a reliable index, and in these cases we substituted the state-level search frequency. On this index, the five most racist metropolitan areas were Flint, MI, Altoona, PA, Charleston, WV, Scranton, PA, and Wheeling, WV. The five least racist were Salt Lake City, UT, Ogden, UT, ProvoOrem, UT, Honolulu, HI, and Napa, CA.

When we entered various pejorative terms for Asians (chink, gook, etc.) into Google Trends, we did not find a sufficient volume of searches to provide a reliable index of Anti-Asian bias across metropolitan areas, suggesting a much lower level of hostility against this group. Likewise, when we entered various pejorative terms for Latinos into the system (spic, beaner, etc.) we also came up empty. However, recent decades have seen the rise of a Latino threat narrative in the media and public discourse tied to the framing of Latino immigrants as "illegal" (owing to undocumented migration) and therefore by definition "criminals" and "lawbreakers" (Chavez 2001, 2008). When we entered variations on the term "illegal immigrant" into Google Trends we again encountered a rather large volume of searches that yielded a robust and variable distribution of frequencies across metropolitan areas. As before, we substituted the state-level frequency whenever the volume was too low to sustain measurement within a particular metropolitan area. According to this index the lowest levels of anti-Latino sentiment were observed in Honolulu, HI, Bangor, ME, Cleveland, OH, Detroit, MI, and Lewiston, ME, whereas the highest levels occurred in Santa Barbara, CA, El Paso, TX, Brownsville, TX, Phoenix, $\mathrm{AZ}$, and Tucson, AZ.

In addition to White animus toward certain minority groups, as noted above researchers have also demonstrated a strong causal connection between restrictive density zoning and both class and racial segregation (Rothwell and Massey, 2009, 2010). In their survey of local land regulations prevailing in forty-nine metropolitan areas, Pendall et al. (2006) asked 1,677 governmental units to report the maximum allowable density permitted in the jurisdictions they controlled. Localities that allowed less than four units per acre were coded 1 ; those that allowed four to seven units were coded 2 ; those permitting eight to fifteen units were coded 3; those allowing sixteen to thirty were coded 4; and those permitting thirty or more units per acre were coded 5. Rothwell and Massey (2009) computed the average density score across jurisdictions for each metropolitan area and found that it strongly predicted segregation, even after the application of rigorous controls.

In order to establish the causal effect of density zoning on segregation, they derived a prediction equation to estimate the density score as an instrumental variable, using year of statehood as the principal exogenous identifier. We borrowed their prediction equation and used it here to estimate density instruments for all metropolitan areas in our data set according to the following formula (1). Following Rothwell and 
Massey (2009), all predictors are defined as of 1980 except for the intergovernmental transfer variable, which was defined as of 1967 according to their formula.

Density Instrument $=-48.394+$ Year of Statehood * $0.007+$ Percent Black * $-0.006+$ Percent Hispanic $+0.022+\log$ of Population * $-0.080+$ Unionization Rate * $-0.015+$ Intergovernmental Transfers as a Share of Local Revenues * 0.005 + Coastal Location * $0.297+$ Percent Urban * $0.004+$ Share in Manufacturing * $0.021+$ Median Age of Housing * $0.021+$ Percent Homes Owner Occupied * $-0.010+$ Violent Crime Rate ${ }^{*}-0.0002+$ Ratio of Minority to White Median Family Income * 0.114 .

The relative size of minority groups has long been recognized as a key determinant of segregation and discrimination. Sociologists have long argued that larger minority groups pose a greater threat to majority interests than smaller ones, in both symbolic and practical terms (Blalock 1967; Blau 1977; Blauner 1972; Lieberson 1980). Symbolically, a larger minority population increases the visibility and salience of group members in public. Practically, more minority group members intensify competition for scarce public and private resources and can be expected to yield higher levels of residential dissimilarity.

In addition, the minority percentage has a direct mathematical relationship with the $\mathrm{P}^{*}$ isolation index, essentially setting its lower bound. In a metropolitan area that is $20 \%$ Black and $80 \%$ White, for example, the minimum possible isolation index for African Americans is twenty, which would occur when the two groups are evenly distributed across neighborhoods (yielding a dissimilarity index of zero), thereby producing a distribution where every neighborhood is $20 \%$ Black. The upper bound, of course, would be 100, which would occur when all Blacks lived in neighborhoods that were $100 \%$ Black and all Whites lived in neighborhoods that were $100 \%$ White.

To a large extent, therefore, residential isolation is produced in urban areas by the confluence of a high level of dissimilarity with a large percentage of minority group members. Apart from these structural influences, the degree of segregation and isolation has been found to vary according to the socioeconomic status of the group in question (Denton and Massey, 1988; Iceland 2007; Iceland et al., 2005). Given that U.S. housing markets are segmented by price, and that wealth and income continue to vary sharply by race and ethnicity, intergroup differences in socioeconomic status translate into differences in residential status, leading to segregation (Massey and Denton, $1985,1993)$. In general, the greater the gap in socioeconomic status between Whites and minorities, the greater the level of minority segregation and spatial isolation (Alba and Logan, 1991, 1993; Massey and Denton, 1987). Hence our data set includes two indicators of relative status: the ratio of minority to White household income and the ratio of minority to White college graduates. In each case, we used census data to compare minority group members (Blacks, Hispanics, or Asians) to Whites living in the same metropolitan area. In addition, since homeowners have a greater stake in the status of a neighborhood than do renters and thus tend to behave more conservatively in response to perceived threats (Hirsch 1983; Sugrue 1996), we also control for the relative number of homeowners in each metropolitan area.

Research has generally shown that minority segregation and isolation vary systematically by metropolitan demographic circumstances, being greater in metropolitan areas that have more inhabitants (Massey and Denton, 1987, 1988b), more foreign born (Denton and Massey, 1988; Iceland and Scopilliti, 2008), more female-headed households (Massey et al., 1994), and more elderly (Farley and Frey, 1994; Massey 2006). Older Whites tend to be more prejudiced than younger persons (Maykovich 1975; Schuman et al., 1998; St. John 1996) and so are more resistant to residential integration. 
Segregation has also been hypothesized to vary according to patterns of industrial organization, with large manufacturing sectors and high rates of unionization pushing segregation levels upward (Lieberson 1980; Massey and Denton, 1993). In contrast, metropolitan areas dominated by "creative class" service industries, such as finance, insurance, and real estate, tend to be more diverse (Florida 2002). Another indicator of a creative class economy is the rate of patent production, which we also include in the model. Sectoral employment data was drawn from the census whereas the unionization data came from Hirsch and Mcpherson (2012). Patent production was computed as the number of patents per 100,000 persons in the MSA using data on utility patents from the U.S. Patent and Trademark Office.

Researchers have also shown that metropolitan areas dominated by colleges and universities and large military populations are more integrated than others (Farley and Frey, 1994). The military is the most integrated institution in American society and its influence apparently shapes race relations and housing patterns in metropolitan areas that contain them (Moskos and Butler, 1996). Using census data we computed the number of persons living in military quarters per 100,000 persons. Expressions of prejudice decline sharply with education, and in order to assess the dominance of the educational sector in each metropolitan area we computed the proportion of workers employed in education.

We also consider the influence of several facets of urbanism. Since metropolitan areas are constructed from multiple counties, many of which contain significant nonurban populations, we measure the percentage of metropolitan inhabitants who are actually urban residents (living in census tracts with greater than 1,000 persons per square mile). Moreover, given that Whites, on average, continue to associate African Americans with higher rates of crime (Quillian and Pager, 2001, 2010) and resist integration based on this perception (Emerson et al., 2001) we also constructed violent crime rates for MSA's using count data from the U.S. Federal Bureau of Investigation (2012). Metropolitan areas with newer housing stocks built after the civil rights era tend to be less segregated than those areas built up in earlier periods (Farley and Frey, 1994), we drew upon census data to compute the median year in which an MSA's housing was built.

Finally, we control for geographic location by including dummy variables for region (with the Midwest serving as the reference category), a dummy variable for whether the MSA is located on a coast (given that coastal areas tend to have more restrictive building codes and higher housing costs (Glaeser and Gyourko, 2008)), and a final dummy for location in a border state, where levels of Hispanic segregation have historically been higher (Grebler et al., 1970; Massey 1979).

\section{TRENDS IN RESIDENTIAL SEGREGATION AND SPATIAL ISOLATION}

As noted above, group size strongly affects the potential for segregation and isolation experienced by minority members in metropolitan America, so we begin our analysis by showing trends in the number of Hispanics, Blacks, and Asians residing in our panel of 287 metropolitan statistical areas from 1970 through 2010. As seen in Figure 1, the greatest change in the nation's racial-ethnic makeup over past four decades has been the remarkable growth of the Hispanic population, which surged from eight million to forty-five million persons and went from $4.7 \%$ to $16.3 \%$ of the population of these MSAs. The number of Asians also grew very rapidly, expanding by a factor of more than ten, but from a much smaller base, going from 1.5 million in 1970 to sixteen million in 2010 and raising their share of the population from $0.8 \%$ to $4.7 \%$. Over the same 


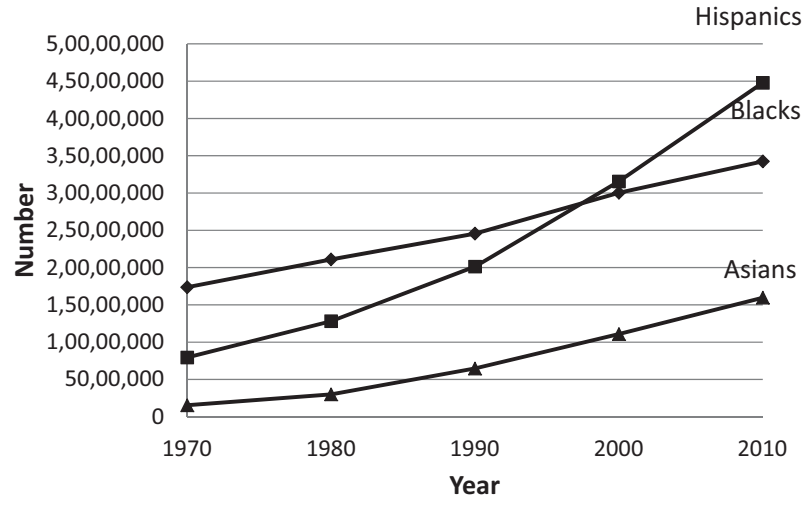

Fig. 1. Growth of Minorities in U.S. Metropolitan Areas 1970-2010

period, the number African Americans roughly doubled in size, going from 17.4 to 34.2 million, but their share of the population climbed upward only slowly, going from $11.1 \%$ to $12.6 \%$ owing mainly to immigration from Africa and the Caribbean. In strictly demographic terms, then, we can say that the potential for segregation and isolation in metropolitan America increased sharply for Hispanics and to a lesser extent for Asians, but shifted little for African Americans.

Figure 2 shows average values of residential dissimilarity with respect to nonHispanic Whites for Blacks, Hispanics, and Asians in the 287 metropolitan areas from 1970 to 2010. The average values were computed by weighting the dissimilarity for each metropolitan area by the size of the minority population. Thus the average index for Blacks in 2010 gives the degree of neighborhood segregation experienced by the average Black inhabitant of the 287 metropolitan areas in that year. In considering tract-level residential dissimilarities, index values below 30 are conventionally considered "low;" those between 30 and 60 are viewed as "moderate;" those above 60 are seen as "high;" while any value above 75 is labeled "extreme" (Massey and Denton, 1988a).

According to these standards, over the past four decades African American segregation has fallen from extreme to merely high levels. The pace of the decline was roughly linear, with the index dropping from an average value of 78 in 1970 to reach 60 , the lower boundary of the high range, in 2010, a decline of about 4.5 index points per decade. The prevailing trend in Black-White segregation is thus one of moderate but steady decline. Nonetheless, at the current rate of change, average Black-White

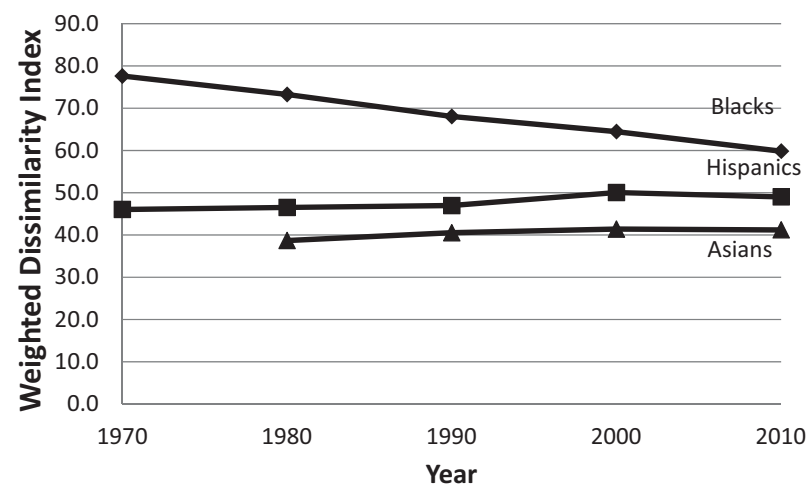

Fig. 2. Trends in Neighborhood-Level Dissimilarity from Whites 1970-2010 
residential dissimilarity would not reach the upper threshold of the low range for another sixty-seven years.

In contrast to the pattern of steady decline observed for Blacks, the prevailing pattern of residential dissimilarity for Hispanics and Asians is one of relative stasis. Despite the massive increase in the size of both groups, dissimilarity indices for Hispanics and Asians rose only slightly over the past four decades. Average Hispanic-White dissimilarity rose from a value of 46 in 1970 to 49 in 2010 while average Asian-White dissimilarity only rose from 39 to 41 between 1980 and 2010. Such stability in residential dissimilarity in the face of rapid population growth is remarkable. Whereas in the twentieth century the growth of Black urban populations spurred Whites to practice more intense exclusion and discrimination that yielded sharply rising BlackWhite dissimilarities (Lieberson 1980; Massey and Denton, 1993; Sugrue 1996), the rapid growth of metropolitan Hispanic and Asian populations from 1970 to 2010 does not appear to have triggered a comparable surge in Hispanic-White or Asian-White segregation. The contrasting experience of African Americans in the early twentieth century compared with that of Hispanics and Asians today implies that rising numbers of African Americans then posed a much greater threat to Whites than rising numbers of Hispanics and Asians do today.

When it comes to spatial isolation, both substantive and mathematical effects are relevant in determining index values because the $\mathrm{P}^{*}$ index is a mathematical function of the minority percentage. It necessarily increases as the minority percentage rises no matter how Whites react to a growing minority presence or how dissimilarity changes. Indeed, even if residential dissimilarity were to remain constant, the isolation index would increase if the minority percentage were to rise. For African Americans, then, the trend in spatial isolation is expected to depend on which process has more force in determining index values: the slight increase in the demographic potential for isolation attributable to the slow increase in the Black percentage over the four decades or the faster decline in the structural potential for segregation brought about the slow but steady decrease in residential dissimilarity.

As Figure 3 shows, the effect of the steadily decline in Black dissimilarity appears to outweigh the modest increase in the relative size of the urban Black population in determining Black isolation. As before, we computed size-weighted isolation indices for Blacks, Hispanics, and Asians from 1970 through 2010. The degree of spatial isolation experienced by African Americans decreased linearly at roughly the same rate as the decline in dissimilarity, falling by an average of 4.8 points per decade and dropping from a value of 65 in 1970 to 46 in 2010. In contrast, Hispanic isolation increased

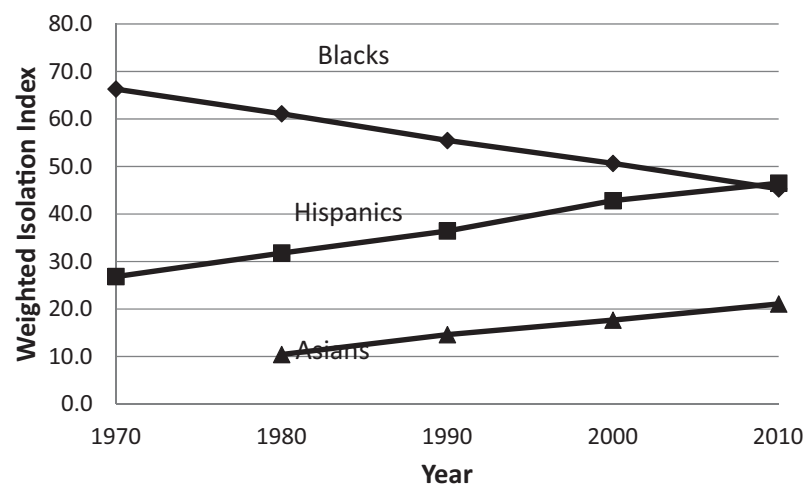

Fig. 3. Trends in Neighborhood-Level Isolation Indices 1970-2010 
quite sharply, as we would expect given the large increase in group size combined with slowly rising dissimilarity. The Hispanic isolation index rose from 27 to 47 over the period, an increase of around 5 points per decade. We also observe an increase in Asian spatial isolation, which went from an index value of 10 in 1980 to reach 21 in 2010. Given their small share of most metropolitan populations, however, the pace of the increase was only about 3.7 points per decade for Asians, and even the value of 21 in 2010 indicates a relatively low level of Asian spatial isolation.

In sum, Black dissimilarity and isolation indices have both steadily declined over the past four decades at a rate of around 5 points per decade and the average level of Black-White dissimilarity now lies at the frontier between "high" and "moderate" segregation with an index value of 60 . In contrast, dissimilarity and isolation have both increased for Hispanics and Asians. Although the increase in dissimilarity has been slight and in 2010 both remained well within the "moderate" range of segregation, increases in the size of the Asian and Hispanic populations have pushed isolation indices upward. Although the rate of Asian growth has been sharp, the relative size of the population has remained small in most metropolitan areas and average isolation remains quite low with an index value of 20. Among Hispanics, however, rapid rates of urban population growth has combined with very large absolute numbers have increased spatial isolation to levels comparable to those of African Americans. As of 2010, the average isolation index stood at roughly 46 for both groups.

Despite the impressive shifts toward integration by African Americans overall, the declines have been quite uneven across metropolitan areas. In general, levels of segregation and isolation are much higher and the declines considerably slower among large metropolitan areas with large Black populations. Indeed, in their analysis of residential segregation in the fifty largest metropolitan areas of 1980, Massey and Denton (1989, 1993) identified sixteen areas in which African Americans experienced a uniquely intense form of segregation across multiple geographic dimensions, a condition they labeled "hypersegregation." Neither Hispanics nor Asians experienced hypersegregation in the metropolitan areas they examined. Wilkes and Iceland (2004) updated the analysis using 2000 census data for all metropolitan areas and identified twenty-nine metropolitan areas in which African Americans were hypersegregated. Although Asians still did not experience hypersegregation in any metropolitan area, by 2000 hypersegregation for Hispanics had emerged in the Los Angeles and New York metropolitan areas.

In Figure 4 we consider trends in residential segregation and spatial isolation for Hispanics and Blacks in those areas identified as hypersegregated in 2000. These

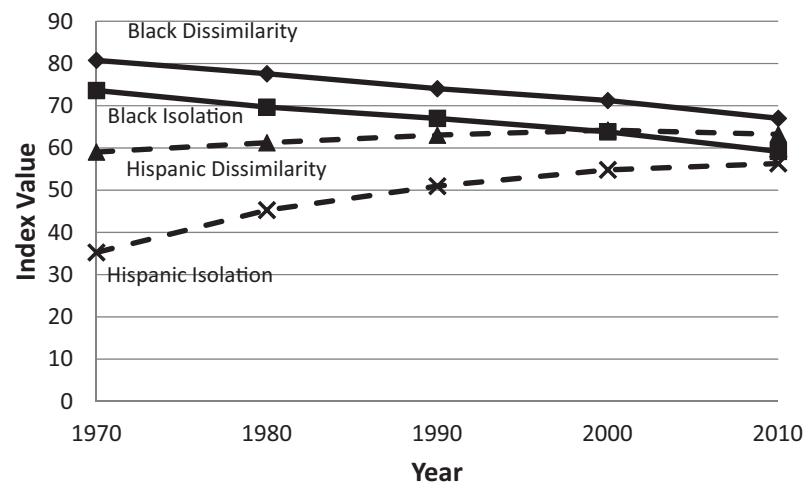

Fig. 4. Trends in Segregation and Isolation within Hypersegregated Metropolitan Areas 
metropolitan areas contain roughly a third of all African Americans in the United States and nearly half of those who live in metropolitan areas, and they account for $16 \%$ of all Latinos and close to $20 \%$ of metropolitan Latinos. Obviously in these metropolitan areas that house a disproportionate share of Blacks and Hispanics levels of segregation and isolation are considerably higher and downward trends are far more limited than among metropolitan areas in general. Among hypersegregated Black areas dissimilarity falls from 81 to 67 and isolation drops from 74 to 59 for a decline of only 3.5-3.7 points per year, leaving Black-White dissimilarity well within the high range in 2010 and isolation at a very elevated level. In the two hypersegregated Hispanic areas, moreover, levels of dissimilarity and isolation rose such that both came to roughly equal those observed in Black hypersegregated areas.

Finally, we consider what neighborhood circumstances look like from the viewpoint of non-Hispanic Whites. To this point our analyses of neighborhood composition have relied strictly on the $\mathrm{P}^{*}$ isolation index, but $\mathrm{P}^{*}$ actually refers to a family of isolation and contact indices. The isolation index gives the average likelihood of within-neighborhood contact with members of one's own group whereas contact indices give the likelihood of within-neighborhood contact with members of other groups. Within any metropolitan area, the isolation and contact indices for any given group must sum up to 100 . Figure 5 examines how the world has changed for Whites by presenting weighted averages computed to measure the degree of own-group isolation and intergroup contact for Whites residing in neighborhoods of the 287 metropolitan areas between 1970 and 2010.

These figures underscore the asymmetric nature residential experiences for minority and majority group members in metropolitan areas, for despite the steady declines in Black segregation, falling Black isolation, the massive increase of Hispanics, and the large increase of Asians within metropolitan areas, Whites still inhabit overwhelmingly White neighborhoods. Although the White isolation index dropped from a value of 91 in 1970 to 74 in 2010 - some 4.4 points per decade-the starting point constituted a very extreme level of isolation. Moreover, despite the shift in White isolation, the average White American still lived in a neighborhood that was roughly three-quarters White in 2010, a time when the United States as a whole was only $63 \%$ White and that share was rapidly falling.

Mixing within neighborhoods likewise has not kept pace with the changing racialethnic composition of the nation for the shift away from White isolation involved relatively small changes in the degree of contact with minority group members. In the four decades from 1970 to 2010, for example, the likelihood of White neighborhood

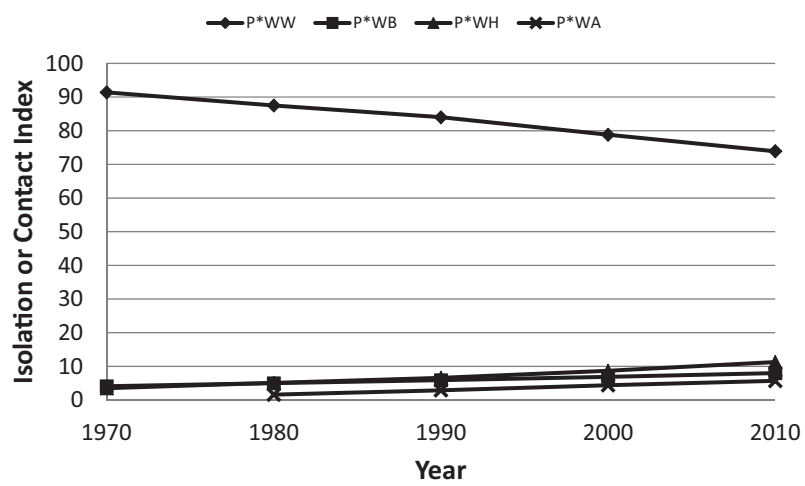

Fig. 5. Trends in White Isolation and Contact Indices 
contact with African Americans rose by less than 1 point per decade to yield an index value of 8 in 2010; contact with Asians grew by just 1.4 point per decade to reach a value of 6 in 2010; and contact with Hispanics rose by only 2 points per decade to achieve a value of 11 . It is only through the combined effect of rising contact with Hispanics, Blacks, and Asians together that White isolation fell to the extent observed. Considered on a group-by-group basis, contact probabilities with minority groups remain minuscule. In the end, the vast majority of Whites do not experience the rising racial-ethnic diversity of contemporary America.

\section{EXPLAINING CONTEMPORARY SEGREGATION AND ISOLATION}

In order to isolate the principal drivers of segregation and integration we estimated the effect of the independent variables described in Table 1 on levels of residential dissimilarity and spatial isolation in 2010. We also assess the determinants of change from 1980 to 2010 by regressing changes in dissimilarity and isolation scores on changes in the values of the various independent variables over the period. Rather than estimating separate models for African Americans, Hispanics, and Asians, for economy of presentation we concatenate data for the three groups into a single file and include dummy variables to indicate which group's segregation is being measured as the dependent variable. All independent variables pertain to the metropolitan area population as a whole except for the indices of racism and illegal immigration, which are specific to Blacks and Hispanics, respectively, and the ratios of minority/White income and minority/White college graduates which are defined with respect to Blacks, Hispanics, and Asians when regressed on dissimilarities defined for the same three groups.

As of 2010, the group dummy variables in the first panel indicate that if other factors in the model were equal, Hispanics would exhibit a residential dissimilarity from Whites that was 20.3 points below that of Asians $(\mathrm{p}<0.001)$ whereas African Americans would display a dissimilarity 5.5 points lower (n.s.). In fact, Asians are far less segregated from Whites than either Blacks or Hispanics, which implies that other things are decidedly not equal. In the second panel of Table 2 we interact these indices of antiBlack and anti-Latino sentiment with the dummy variables for membership in each group. Results indicate that anti-Black racism has a powerful and highly significant effect in predicting the level of Black-White segregation. Each point increase in the anti-Black index raises the expected level of Black-White dissimilarity by 2.09 points, potentially raising the dissimilarity index by 15 points over the observed range of the scale. Among Latinos, the effect is even more pronounced. Each point increase in the anti-Latino index raises Hispanic-White dissimilarity by 3.4 points, potentially raising Hispanic dissimilarity by 23 points over the observed range of the index.

As expected, the density instrument also strongly predicts the degree of racialethnic segregation across metropolitan areas. In this case, a higher density score indicates a more permissive zoning regime, allowing a higher average level of residential density. As can be seen, higher allowable densities are associated with significantly lower levels of residential dissimilarity. Moving the index from its observed minimum to its observed maxim would reduce residential dissimilarity by 16 points.

Also as expected, residential dissimilarity is predicted by the relative size of the minority population. Each point increase in the percentage of Blacks raises dissimilarity by 0.235 points, yielding a potential increase of 12 points as the percentage goes from its observed minimum to maximum. Likewise, each point increase in the percentage of Hispanics raises dissimilarity by 0.163 points, yielding a potential shift of 15 points from its minimum to maximum. Although the coefficient is only marginally significant 
Table 2. Effect of Selected Variables on Minority-White Residential Dissimilarity in 2010 and 1980-2010 Change

\begin{tabular}{|c|c|c|c|c|}
\hline \multirow[b]{2}{*}{ Independent Variable } & \multicolumn{2}{|c|}{ Dissimilarity in 2010} & \multicolumn{2}{|c|}{ Change 1980-2010 } \\
\hline & B & SE & B & SE \\
\hline \multicolumn{5}{|l|}{ Minority Group } \\
\hline Asians & - & - & - & - \\
\hline Hispanics & $-20.266^{* * *}$ & 3.064 & $7.828^{* *}$ & 2.965 \\
\hline Blacks & -5.523 & 3.333 & $-21.335^{* * *}$ & 3.356 \\
\hline \multicolumn{5}{|l|}{ Racial Prejudice } \\
\hline Anti-Black Index & -0.409 & 0.431 & -0.509 & 0.428 \\
\hline Anti-Black Index * Black & $2.096^{* * *}$ & 0.485 & $1.387^{\text {** }}$ & 0.467 \\
\hline Anti-Latino Index & -0.252 & 0.394 & -0.479 & 0.503 \\
\hline Anti-Latino Index * Hispanics & $3.384^{* * *}$ & 0.482 & $1.147^{* *}$ & 0.411 \\
\hline \multicolumn{5}{|l|}{ Zoning Regime } \\
\hline Density Permissiveness & $-4.265^{* *}$ & 1.364 & $-3.716^{* *}$ & 1.145 \\
\hline \multicolumn{5}{|l|}{ Minority Composition } \\
\hline Percent Black & $0.235^{\star *}$ & 0.071 & 0.034 & 0.143 \\
\hline Percent Hispanic & $0.163^{*}$ & 0.067 & $-0.333^{* *}$ & 0.120 \\
\hline Percent Asian & $0.301+$ & 0.167 & 0.032 & 0.217 \\
\hline \multicolumn{5}{|l|}{ Socioeconomic Status } \\
\hline Ratio Minority/White HH Income & $-6.652^{* * *}$ & 1.871 & $-3.173^{* *}$ & 1.207 \\
\hline Ratio Minority/White College Grad & $-0.929+$ & 0.874 & $-1.991+$ & 0.746 \\
\hline Percent Homeowner & 0.104 & 0.079 & 0.062 & 0.128 \\
\hline Affluent Poor Dissimilarity & $0.169^{* *}$ & 0.063 & -0.086 & 0.070 \\
\hline \multicolumn{5}{|l|}{ Population } \\
\hline Log MSA Population & $3.470^{* * *}$ & 0.483 & -0.727 & 0.440 \\
\hline Percent Foreign Born & $0.147+$ & 0.131 & $0.879^{* * *}$ & 0.205 \\
\hline Percent Female Headed HH & -0.453 & 0.297 & -0.283 & 0.235 \\
\hline Percent Aged 65+ & 0.039 & 0.165 & -0.200 & 0.222 \\
\hline \multicolumn{5}{|l|}{ Industrial Organization } \\
\hline Percent Manufacturing & 0.138 & 0.093 & 0.051 & 0.081 \\
\hline Percent FIRE & 0.258 & 0.220 & 0.025 & 0.261 \\
\hline Percent Education & 0.005 & 0.132 & 0.087 & 0.314 \\
\hline Log Military Population & $-0.503^{* * *}$ & 0.121 & 0.677 & 0.780 \\
\hline Percent Unionized & 0.035 & 0.063 & $0.294^{* *}$ & 0.101 \\
\hline Patents per Capita & -0.013 & 0.008 & -0.003 & 0.010 \\
\hline \multicolumn{5}{|l|}{ Urbanism } \\
\hline Percent Urban & $-0.097^{*}$ & 0.044 & 0.002 & 0.057 \\
\hline Violent Crime Rate & $0.003+$ & 0.002 & $0.003+$ & 0.002 \\
\hline Median Year Housing & $-0.271^{* * *}$ & 0.058 & 0.034 & 0.073 \\
\hline \multicolumn{5}{|l|}{ Geography } \\
\hline Northeast & 0.538 & 1.272 & -0.638 & 1.172 \\
\hline South & 0.665 & 1.103 & 0.015 & 1.132 \\
\hline West & $-4.412^{* *}$ & 1.359 & -0.391 & 1.338 \\
\hline
\end{tabular}


Table 2. (continued)

\begin{tabular}{|c|c|c|c|c|}
\hline \multirow[b]{2}{*}{ Independent Variable } & \multicolumn{2}{|c|}{ Dissimilarity in 2010} & \multicolumn{2}{|c|}{ Change 1980-2010 } \\
\hline & B & SE & B & SE \\
\hline Coastal & -0.074 & 0.948 & -1.458 & 0.938 \\
\hline Border & $2.617^{*}$ & 1.214 & -1.591 & 1.339 \\
\hline Constant & $539.710^{* *}$ & 111.520 & -45.080 & 139.480 \\
\hline $\mathbf{N}$ & \multicolumn{2}{|c|}{825} & \multicolumn{2}{|c|}{825} \\
\hline $\mathbf{R}^{2}$ & \multicolumn{2}{|c|}{0.50} & \multicolumn{2}{|c|}{0.62} \\
\hline
\end{tabular}

${ }^{* * *} p<.001{ }^{* *} p<.01{ }^{*} p<.05+p<.10($ Note: Number of MSAs $=275)$

$(\mathrm{p}<0.10)$, each point increase in the percentage of Asians raises dissimilarity by 0.301 points, yielding a potential shift of 21 points over the observed range of percentages.

Aside from their relative numbers, the relative income of each minority group strongly predicts the residential dissimilarity they experience. Each point increase in the ratio of minority to White household income lowers residential dissimilarity by 6.65 points. Among African Americans the income ratio varies from 0.17 to 1.14 , yielding a potential drop in dissimilarity of 6.5 points over the range of the index. Among Hispanics the range is from 0.31 to 1.43 , yielding a potential drop of 7.5 points; but among Asians the range goes from 0.35 to 2.81 yielding a potential decline of 16.4 points. Thus, one important reason for the lower level of Asian-White dissimilarity is the relatively high incomes earned by Asians, which in most metropolitan areas top those of Whites. The ratio of college-educated minority members to college educated Whites works in the same direction-lowering levels of residential dissimilarity-but the effect is much weaker and only marginally significant. Racial-ethnic segregation, however, is quite strongly and positively associated with the degree of class segregation. The residential dissimilarity between the affluent and the poor is potentially responsible for an upward shift of 6 points in the level of racial-ethnic dissimilarity as it goes from its observed minimum to maximum.

As other researchers have found, we also find that racial-ethnic segregation is greater in large metropolitan areas and lower in areas with a sizeable military presence and in those with a newer housing stock. Each point increase in the log of metropolitan population increases residential dissimilarity by 3.47 points potentially accounting for a shift of 17 points from the smallest to the largest metropolitan area. However, each point increase in the log of the military population per 100,000 persons reduces racial-ethnic dissimilarity by 0.503 points whereas each year increase in the median year of housing lowers it by 0.271 points, yielding potential reductions of 4 points and 12 points, respectively, as these variables range from minimum to maximum. A few of our other substantive predictors-percent foreign born, percent urban, and the violent crime rate-also predict racial-ethnic segregation but the effects are weak and usually only of marginal significance. Among geographic effects, we see that levels or racial and ethnic segregation are systematically lower in the West (by 4.412 points) compared with the Midwest and systematically higher in border states (by 2.617 points) than elsewhere in the country.

The right-hand columns show a model predicting change in racial-ethnic dissimilarity between 1980 and 2010. The dummy variables indicating group membership, the prejudice indices, the density instrument, and the geographic indicators are all timeinvariant but all other variables are defined in terms of their change between 1980 and 
2010. As we would expect given trends already reported, the coefficient for Hispanics is positive and significant (7.828), the coefficient for Blacks is negative and significant, $(-21.335)$ indicating that, other things equal, Hispanic segregation increased over the three decades while Black segregation decreased. In both cases, however, shifts toward integration were impeded by higher levels of anti-Black or anti-Latino sentiment, and across metropolitan areas by more restrictive regimes of density zoning. Holding constant anti-Latino sentiment, however, an increase in the percentage Hispanic was associated with a lower level of residential dissimilarity. Rising minority income relative to Whites was strongly associated with declining residential dissimilarity, as was rising education relative to Whites, though as in the cross-sectional model the latter effect was much weaker an only marginally significant. Not surprisingly, immigration, as measured by a rising share of foreign born, was strongly associated with rising residential dissimilarity as was the metropolitan rate of unionization.

Table 3 presents regressions to predict the degree of spatial isolation in 2010 as well as changes in isolation between 1980 and 2010, conditional on the observed level of residential dissimilarity. The degree of spatial isolation experienced by a group largely follows from its relative size and the degree of residential dissimilarity it experiences. It is no surprise, therefore to discover that residential dissimilarity and minority percentages very powerfully predict the level of isolation in 2010 as well as changes from 1980 to 2010. These findings are not substantively interesting since they follow directly from the definition and properties of the $\mathrm{P}^{*}$ index. What is of interest here is the other factors that contribute to spatial isolation above and beyond these mathematical determinants.

As can be seen, the principal determinant of spatial isolation beyond dissimilarity and minority composition is the extent of racial prejudice, which acts to intensify isolation in the cross section and forestall reductions over time. Each point increase in anti-Black sentiment increases the spatial isolation of African Americans by 6.049 points and is associated with an increase of 1.103 points in isolation over time, yielding potential shifts of 42 points in the degree of isolation and 8 points of change in isolation over the observed range of anti-Black prejudice. Likewise, each point increase in anti-Latino sentiment is associated with an increase of 9.084 points in the degree of Hispanic spatial isolation and a 2.152 point increase in isolation over time, yielding potential shifts of 61 points of isolation and 14 points of change in isolation over the observed range of the prejudice index. Beyond these effects, not much else affects the level of spatial isolation. The only strong effect is the effect of a higher relative level of minority education, which promotes a decline in racial-ethnic isolation over time. The zoning instrument has no effect, implying that its influence on spatial isolation occurs entirely through its strong effect on residential dissimilarity.

\section{CONCLUSION}

The foregoing analyses reveal that the United States is neither moving toward the end of the segregated century nor resting at a point of stalled integration. Rather, Black and Hispanic segregation and spatial isolation continue to be actively produced in some metropolitan areas while being mitigated in others. On the one hand, segregated metropolitan areas are those of large size with relatively large but poor minority populations, an older stock of housing, a restrictive regime of density zoning, little military presence, and rapid immigration. In addition to these structural metropolitan circumstances, segregation and isolation are boosted by a high degree of anti-Black or anti-Latino sentiment. According to our analyses, those metropolitan areas that are 
Table 3. Effect of Selected Variables on Spatial Isolation in 2010 and 1980-2010 Change

\begin{tabular}{|c|c|c|c|c|}
\hline \multirow[b]{2}{*}{ Independent Variable } & \multicolumn{2}{|c|}{ Isolation in 2010} & \multicolumn{2}{|c|}{ Change 1980-2010 } \\
\hline & B & SE & B & SE \\
\hline \multicolumn{5}{|l|}{ Structural Segregation } \\
\hline Minority-White Dissimilarity & $0.753^{* * *}$ & 0.058 & $0.399^{* * *}$ & 0.030 \\
\hline \multicolumn{5}{|l|}{ Minority Group } \\
\hline Asians & - & - & - & - \\
\hline Hispanics & $-42.769^{* * *}$ & 5.171 & $-8.633^{* * *}$ & 2.332 \\
\hline Blacks & $-33.533^{* * *}$ & 4.579 & $-15.175^{* * *}$ & 3.315 \\
\hline \multicolumn{5}{|l|}{ Racial Prejudice } \\
\hline Anti-Black Index & $-1.834^{* * *}$ & 0.467 & -0.189 & 0.286 \\
\hline Anti-Black Index * Black & $6.049^{* * *}$ & 0.717 & $1.103^{*}$ & 0.448 \\
\hline Anti-Latino Index & $-3.595^{* * *}$ & 0.587 & -0.458 & 0.354 \\
\hline Anti-Latino Index ${ }^{*}$ Hispanics & $9.084^{* * *}$ & 0.881 & $2.152^{* * *}$ & 0.391 \\
\hline \multicolumn{5}{|l|}{ Zoning Regime } \\
\hline Density Permissiveness & 1.290 & 1.824 & 1.132 & 0.838 \\
\hline \multicolumn{5}{|l|}{ Minority Composition } \\
\hline Percent Black & $0.335^{\star *}$ & 0.114 & $0.343^{* * *}$ & 0.105 \\
\hline Percent Hispanic & $0.258^{* *}$ & 0.110 & $0.304^{* * *}$ & 0.092 \\
\hline Percent Asian & 0.081 & 0.232 & $0.484^{*}$ & 0.205 \\
\hline \multicolumn{5}{|l|}{ Socioeconomic Status } \\
\hline Ratio Minority/White HH Income & -1.639 & 1.794 & -1.007 & 0.761 \\
\hline Ratio Minority/White College Grad & -0.214 & 0.886 & $-1.499^{* * *}$ & 0.433 \\
\hline Percent Homeowner & 0.000 & 0.114 & $0.216^{*}$ & 0.090 \\
\hline Affluent Poor Dissimilarity & -0.004 & 0.085 & -0.001 & 0.053 \\
\hline \multicolumn{5}{|l|}{ Population } \\
\hline Log MSA Population & -0.508 & 0.572 & $-0.833^{*}$ & 0.329 \\
\hline Percent Foreign Born & 0.031 & 0.209 & -0.085 & 0.177 \\
\hline Percent Female Headed HH & -0.051 & 0.480 & 0.250 & 0.173 \\
\hline Percent Aged 65+ & 0.101 & 0.210 & 0.023 & 0.172 \\
\hline \multicolumn{5}{|l|}{ Industrial Organization } \\
\hline Percent Manufacturing & -0.079 & 0.104 & -0.032 & 0.059 \\
\hline Percent FIRE & -0.248 & 0.192 & 0.173 & 0.187 \\
\hline Percent Education & -0.003 & 0.156 & $-0.461+$ & 0.257 \\
\hline Log Military Population & 0.162 & 0.192 & 0.085 & 0.519 \\
\hline Percent Unionized & 0.004 & 0.011 & -0.017 & 0.068 \\
\hline Patents per Capita & 0.115 & 0.054 & 0.002 & 0.010 \\
\hline \multicolumn{5}{|l|}{ Urbanism } \\
\hline Percent Urban & $0.115^{*}$ & 0.054 & -0.011 & 0.035 \\
\hline Violent Crime Rate & 0.000 & 0.003 & 0.001 & 0.001 \\
\hline Median Year Housing & 0.025 & 0.077 & -0.080 & 0.062 \\
\hline \multicolumn{5}{|l|}{ Geography } \\
\hline Midwest & - & - & - & - \\
\hline Northeast & -1.437 & 1.439 & 1.287 & 0.926 \\
\hline
\end{tabular}


Table 3. (continued)

\begin{tabular}{|c|c|c|c|c|}
\hline \multirow[b]{2}{*}{ Independent Variable } & \multicolumn{2}{|c|}{ Isolation in 2010} & \multicolumn{2}{|c|}{ Change 1980-2010 } \\
\hline & B & SE & B & SE \\
\hline South & -0.491 & 1.423 & -0.507 & 0.854 \\
\hline West & 2.292 & 1.702 & $2.396^{*}$ & 1.079 \\
\hline Coastal & -0.202 & 1.389 & -0.152 & 0.799 \\
\hline Border & -1.004 & 1.729 & -2.407 & 1.254 \\
\hline Constant & -45.539 & 151.241 & 167.705 & 120.705 \\
\hline $\mathbf{N}$ & \multicolumn{2}{|c|}{825} & \multicolumn{2}{|c|}{825} \\
\hline $\mathbf{R}^{2}$ & \multicolumn{2}{|c|}{0.72} & \multicolumn{2}{|c|}{0.68} \\
\hline
\end{tabular}

${ }^{* * *} p<.001{ }^{* *} p<.01{ }^{*} p<.05+p<.10$ (Note: Number of MSAs $\left.=275\right)$

integrating over time are those having relatively affluent and well-educated minority populations, low levels of anti-Black and anti-Latino sentiment, low rates of immigration, and permissive regimes of density zoning.

These forces yield a varied panorama of trends, with segregation and isolation falling sharply in some areas but persisting at high levels in others. Although Asians generally experience very moderate levels of segregation and little isolation wherever they live, Blacks continue to experience high segregation and little progress toward integration in many metropolitan areas while Hispanics display rising levels of segregation and isolation in other areas. In both cases, metropolitan areas displaying high segregation and little progress toward integration house a disproportionate number of minority group members. As a result, hypersegregation continues to characterize the residential experience of a large share of both African Americans and Hispanics even as some areas move rapidly toward integration.

The contrast is well illustrated by the two extremes of the distribution of metropolitan areas by residential dissimilarity. Figure 6 shows trends in Black-White dissimilarity for the five most and five least racially segregated metropolitan areas in 2010. As can be seen, Black segregation fell sharply in Provo, UT, Missoula, MT, as well as in Boulder, Fort Collins, and Grand Junction, CO-all small metropolitan areas in western states with small, relatively affluent Black populations characterized by low levels of prejudice and a relative absence of restrictive density zoning regulations.

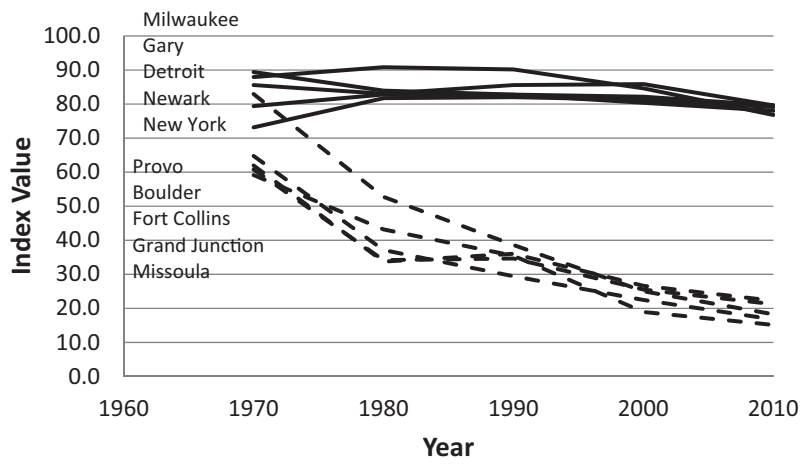

Fig. 6. Trends in Black-White Dissimilarity in Five Most and Five Least Segregated Metropolitan Areas 
In addition, Provo, Fort Collins, Missoula, and Boulder also happen to be college towns, which Farley and Frey (1994) found generally display lower levels of racial segregation.

In contrast, Black segregation persisted virtually unchanged at extremely high levels in Milwaukee, WI, Gary, IN, Detroit, MI and New York-large metropolitan areas with sizeable, poor Black communities in areas characterized by a relatively high level of anti-Black prejudice and restrictive density zoning regimes. Thus, in the five most segregated areas, the average Black percentage was high at $23.8 \%$, the average zoning score was relatively restrictive at 2.97 , and the average index of anti-Black sentiment stood at 68.8. In contrast, across the five least segregated areas the average Black percentage stood at just $1.0 \%$, the average density score was almost a point more permissive at 3.82, and the average index of anti-Black sentiment was more than ten points lower at 54.6.

Figure 7 shows comparable trends for Hispanic-White dissimilarity in the five most and least segregated areas for Hispanics in 2010. Sharp declines in segregation are observed in Bangor, ME, Monroe, MI, Spokane, WA, Missoula, MT, and Lawton, $\mathrm{OK}$ - generally small metropolitan areas with relatively small, slowly growing Hispanic populations characterized by low levels of immigration, little anti-Latino sentiment, and permissive density zoning regimes. At the same time, increases in segregation were observed in the two largest areas of Hispanic settlement, New York and Los Angeles (which became hypersegregated during the period). In addition, three smaller metropolitan areas experienced rapid immigration and Hispanic population growth in areas characterized by restrictive zoning regimes and notable anti-immigrant sentiment-Springfield and Peabody, MA and Reading, PA.

The latter areas also have historically housed predominantly Puerto Rican populations, which have long experienced greater segregation levels than other Hispanic groups owing to their Afro-Caribbean heritage (Denton and Massey, 1989; Massey and Bitterman, 1985). Nonetheless, all three metropolitan areas experienced rapid Hispanic population growth driven largely by immigration from other Latin American nations, which in two cases dramatically reduced the relative share of Puerto Ricans. By 2010 only 28\% of Hispanics in Peabody were Puerto Rican and just 56\% were Puerto Rican in Reading (the figure remained high at $85 \%$ in Springfield). In any event, the five most segregated metropolitan areas for Hispanics exhibited an average Hispanic percentage of $24.7 \%$ and a change of 13.9 points since 1980 , compared with figures of just $4.5 \%$ and 1.7 in the five least segregated areas. Likewise, the density index was less

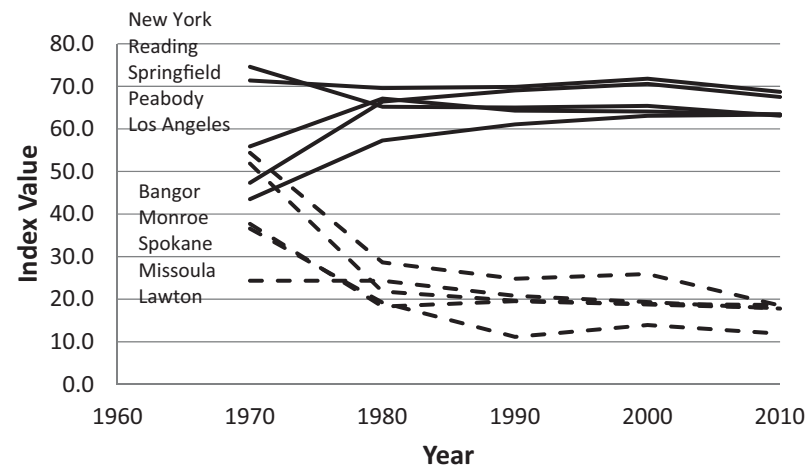

Fig. 7. Trends in Hispanic-White Dissimilarity in Five Most and Five Least Segregated Metropolitan Areas 
permissive at 3.12 compared with 3.58 in the least segregated areas and anti-Latino sentiment was greater at 60 compared with 50 .

In sum, the situation with respect to residential segregation and spatial isolation has become substantially more varied across metropolitan America since 1980. For African Americans, the ghetto has shifted from being a universal feature of urban life to being a variable condition associated with metropolitan characteristics such as large population size, a high Black percentage, and elevated levels of racial prejudice. For Latinos, the barrio has become an increasingly common feature of urban life in those metropolitan areas where the percentage of Hispanics is high, the population has been growing because of rapid immigration, and anti-Latino sentiment is high. Across all metropolitan areas, restrictive density zoning has emerged as a strong force producing segregation and isolation for both groups and shifts toward integration are associated with higher minority socioeconomic status. Which trend prevails in the long run-continued segregation or moves toward integrationremains to be seen; but residential segregation clearly is not yet a thing of the past in the United States.

Corresponding author: Jacob S. Rugh, Department of Sociology, Brigham Young University, Provo, UT 84602. E-mail: jacob_rugh@byu.edu.

\section{NOTE}

1. www.socialexplorer.com

\section{REFERENCES}

Alba, Richard D. and John R. Logan (1991). Variations on Two Themes: Racial and Ethnic Patterns in the Attainment of Suburban Residence. Demography, 28(3): 431-453.

Alba, Richard D. and John R. Logan (1993). Minority Proximity to Whites in Suburbs: An Individual-Level Analysis of Segregation. American fournal of Sociology, 98(6): 1388-1427.

Banaji, Mahzarin R. (2001). Implicit Attitudes Can be Measured. In Henry L. Roediger, James S. Nairne, Ian Neath, and Aimee M. Surprenan (Eds.), The Nature of Remembering: Essays in Honor of Robert G. Crowder, pp. 117-150. Washington, DC: American Psychological Association.

Bargh, John A. (2004). Being Here Now: Is Consciousness Necessary for Human Freedom? In J. Greenberg, S. L. Koole, and T. Pyszczynski (Eds.), Handbook of Experimental Existential Psychology, pp. 385-397. New York: Guilford.

Baum, Deborah (2010). John Logan: Census Shows Integration has Slowed to a Standstill. Today at Brown: News, People, and Events at the University. <http://today.brown.edu/articles/2010/12/ logan> (accessed May 28, 2013).

Bertrand, Marriane and Sendhil Mullainathan (2004). Are Emily and Greg More Employable Than Lakisha and Jamal? A Field Experiment on Labor Market Discrimination. American Economic Review, 94: 991-1013.

Blalock, Hubert M. (1967). Toward a Theory of Minority Group Relations. New York: Wiley.

Blau, Peter M. (1977). Inequality and Heterogeneity: A Primitive Theory of Social Structure. New York: Free Press.

Blaune, Robert (1972). Racial Oppression in America. New York: Harper and Row.

Bobo, Lawrence D. (2004). Inequalities that Endure?: Racial Ideology, American Politics, and the Peculiar Role of Social Science. In Maria Krysan and Amanda Lewis (Eds.), Changing Terrain of Race and Ethnicity, pp. 13-42. New York: Russell Sage Foundation.

Bobo, Lawrence D. and Camille Z. Charles (2009). Race in the American Mind: From the Moynihan Report to the Obama Candidacy. Annals of the American Academy of Political and Social Science, 621: 243-259.

Brescia, Raymond H. (2009). Subprime Communities: Reverse Redlining, the Fair Housing Act and Emerging Issues in Litigation Regarding the Subprime Mortgage Crisis. Albany Government Law Review, 2: 164-216.

Charles, Camille Z. (2003). The Dynamics of Racial Residential Segregation. Annual Review of Sociology, 29: 167-207. 
Chavez, Leo R. (2001). Covering Immigration: Population Images and the Politics of the Nation. Berkeley, CA: University of California Press.

Chavez, Leo R. (2008). The Latino Threat: Constructing Immigrants, Citizens, and the Nation. Stanford, CA: Stanford University Press.

Denton, Nancy A. and Douglas S. Massey (1988). Residential Segregation of Blacks, Hispanics, and Asians by Socioeconomic Status and Generation. Social Science Quarterly, 69: 797-817.

Denton, Nancy A. and Douglas S. Massey (1989). Racial Identity among Caribbean Hispanics: The Effect of Double Minority Status on Residential Segregation. American Sociological Review, 54: 790-808.

Emerson, Michael O., Karen J. Chai, and George Yancey (2001). Does Race Matter in Residential Segregation? Exploring the Preferences of White Americans. American Sociological Review, 66(6): 922-935.

Farley, Reynolds and William H. Frey (1994). Changes in the Segregation of Whites from Blacks during the 1980s: Small Steps Toward a More Integrated Society. American Sociological Review, 59(1): 23-45.

Farley, Reynolds, Howard Schuman, Suzanne Bianchi, Diane Colasanto, and Shirley Hatchett (1978). "Chocolate City, Vanilla Suburbs:" Will the Trend Toward Racially Separate Communities Continue? Social Science Research, 7(2): 319-344.

Fischer, Mary J. and Douglas S. Massey (2004). The Social Ecology of Racial Discrimination. City and Community, 3(2): 221-243.

Fiske, Susan T., Hilary Bergsieker, Anne Marie Russell, and L. Williams (2009). Images of Black Americans: Then, "Them," and Now, "Obama!" DuBois Review: Social Science Research on Race, 6(1): 83-101.

Florida, Richard (2002). The Rise Of The Creative Class: And How It's Transforming Work, Leisure, Community And Everyday Life. New York: Basic Books.

Friedman, Samantha and Gregory D. Squires (2005). Does the Community Reinvestment Act Help Minorities Access Traditionally Inaccessible Neighborhoods? Social Problems, 52(2): 209-231.

Grebler, Leo, Joan W. Moore, and Ralph Guzman (1970). The Mexican-American People: The Nation's Second Largest Minority. Glencoe, IL: Free Press.

Glaeser, Edward L. and Joseph Gyourko (2008). Rethinking Federal Housing Policy: How to Make Housing Plentiful and Affordable. Washington, DC: AEI Press.

Glaeser, Edward L., Joseph Gyourko, and Raven Saks (2005). Why Have Housing Prices Gone Up? American Economic Review, 95: 21-39.

Glaeser, Edward and Jacob Vigdor (2012). The End of the Segregated Century: Racial Separation in America's Neighborhood 1890-2010. Civic Report No. 66, Center for State and Local Leadership. <http://www.manhattan-institute.org/pdf/cr_66.pdf> (accessed May 28, 2013).

Hirsch, Arnold R. (1983). Making the Second Ghetto: Race and Housing in Chicago 1940-1960. Cambridge, MA: Cambridge University Press.

Hirsch, Barry T. and David A. Macpherson (2012). Union Membership and Coverage Database from the Current Population Survey. <http://www.unionstats.com> (accessed May 28, 2013).

Iceland, John (2007). Racial and Ethnic Residential Segregation and the Role of Socioeconomic Status: 1980-2000. In John Goering (Ed.), Fragile Rights within Cities: Government, Housing, and Fairness, pp. 127-122. Lanham, MD: Rowman and Littlefield.

Iceland, John (2009). Where We Live Now: Immigration and Race in the United States. Berkeley, CA: University of California Press.

Iceland, John, and Melissa Scopilliti (2008). Immigrant Residential Segregation in U.S. Metropolitan Areas, 1990-2000. Demography, 45(1): 79-94.

Iceland, John, Cicely Sharpe, and Erika Steinmetz (2005). Class Differences in African American Residential Patterns in U.S. Metropolitan Areas: 1990-2000. Social Science Research, 34(1): 252-266.

Keister, Lisa A. (2000). Wealth in America: Trends in Inequality. New York: Cambridge University Press.

Lee, Tiane L. and Susan T. Fiske (2006). Not an Outgroup, Not Yet an Ingroup: Immigrants in the Stereotype Content Model. International fournal of Intercultural Relations, 30: 751-768.

Lieberson, Stanley (1980). A Piece of the Pie: Blacks and White Immigrants Since 1880. Berkeley, CA: University of California Press.

Logan, John R. and Brian J. Stults (2011). The Persistence of Segregation in the Metropolis: New Findings from the 2010 Census. Census Brief prepared for Project US2010. <http:// www.s4.brown.edu/us2010/Data/Report/report2.pdf> (accessed May 28, 2013). 
Logan, John R., Brian J. Stults, and Reynolds Farley (2004). Segregation of Minorities in the Metropolis: Two Decades of Change. Demography, 41(1): 1-22.

Lopez, Mark Hugo, Rich Morin, and Paul Taylor (2010). Illegal Immigration Backlash Worries, Divides Latinos. Pew Hispanic Center. <http://www.pewhispanic.org/files/reports/128.pdf> (accessed May 28, 2013).

Lord, Richard (2004). American Nightmare: Predatory Lending and the Foreclosure of the American Dream. Monroe, ME: Common Courage Press.

Massey, Douglas S. (1979). Residential Segregation of Spanish Americans in U.S. Urbanized Areas. Demography, 16: 553-563.

Massey, Douglas S. (1995). Getting Away with Murder: Segregation and Violent Crime in Urban America. University of Pennsylvania Law Review, 143(5): 1203-1232.

Massey, Douglas S. (2001). Segregation and Violent Crime in Urban America. In Elijah Anderson and Douglas S. Massey (Eds.), Problem of the Century: Racial Stratification in the United States, pp. 317-346. New York: Russell Sage Foundation.

Massey, Douglas S. (2005). Racial Discrimination in Housing: A Moving Target. Social Problems, 52: $148-151$.

Massey, Douglas S. (2006). Strangers in a Strange Land: Humans in an Urbanizing World. New York: W.W. Norton.

Massey, Douglas S. (2007). Categorically Unequal: The American Stratification System. New York: Russell Sage Foundation.

Massey, Douglas S. (2009). Racial Formation in Theory and Practice: The Case of Mexicans in the United States. Race and Social Problems, 1: 12-26.

Massey, Douglas S. (2010). New Faces in New Places: The New Geography of American Immigration. New York: Russell Sage Foundation.

Massey, Douglas S. (2011). The Past and Future of American Civil Rights. Daedalus 140(2): $37-54$.

Massey, Douglas S. and Brooks Bitterman (1985). Explaining the Paradox of Puerto Rican Segregation. Social Forces, 64: 306-331.

Massey, Douglas S. and Nancy A. Denton (1985). Spatial Assimilation as a Socioeconomic Outcome. American Sociological Review, 50: 94-105.

Massey, Douglas S. and Nancy A. Denton (1987). Trends in the Residential Segregation of Blacks, Hispanics, and Asians. American Sociological Review, 52: 802-825.

Massey, Douglas S. and Nancy A. Denton (1988a). The Dimensions of Residential Segregation. Social Forces, 67: 281-315.

Massey, Douglas S. and Nancy A. Denton (1988b). Suburbanization and Segregation in U.S. Metropolitan Areas. American fournal of Sociology, 94: 592-626.

Massey, Douglas S. and Nancy A. Denton (1989). Hypersegregation in U.S. Metropolitan Areas: Black and Hispanic Segregation along Five Dimensions. Demography, 26: 373-393.

Massey, Douglas S. and Nancy A. Denton (1993). American Apartheid: Segregation and the Making of the Underclass. Cambridge, MA: Harvard University Press.

Massey, Douglas S., Nancy A. Denton, and Mitchell L. Eggers (1994). Disentangling the Causes of Concentrated Urban Poverty. International fournal of Group Tensions, 24: 267-316.

Massey, Douglas S. and Mary J. Fischer (2003). In William G. Gale and Janet Rothenberg Pack (Eds.), Brookings-Wharton Papers on Urban Affairs 2003: The Geography of Inequality in the United States 1950-2000, pp. 1-40. Washington, DC: Brookings Institution.

Massey, Douglas S. and Zoltan Hajnal (1995). The Changing Geographic Structure of BlackWhite Segregation in the United States. Social Science Quarterly, 76: 527-542.

Massey, Douglas S. and Garvey Lundy (2001). Use of Black English and Racial Discrimination in Urban Housing Markets: New Methods and Findings. Urban Affairs Review, 36: 470-496.

Massey, Douglas S. and Karen A. Pren (2012a). Unintended Consequences of US Immigration Policy: Explaining the Post-1965 Surge from Latin America. Population and Development Review, 38: 1-29.

Massey, Douglas S. and Karen A. Pren (2012b).Origins of the New Latino Underclass. Race and Social Problems, 4(1): 5-17.

Massey, Douglas S., Jonathan Rothwell, and Thurston Domina (2009). Changing Bases of Segregation in the United States. Annals of the American Academy of Political and Social Science, 626: 74-90.

Massey, Douglas S. and Magaly Sánchez (2010). Brokered Boundaries: Creating Immigrant Identity in Anti-Immigrant Times. New York: Russell Sage Foundation.

Maykovich, Minako K. (1975). Correlates of Racial Prejudice. Fournal of Personality and Social Psychology, 32(6): 1014-1020. 
Moskos, Charles and John Sibley Butler (1996). All That We Can Be: Black Leadership and Racial Integration The Army Way. New York: Basic Books.

National Council of State Legislatures (2012). State Laws Related to Immigrants and Immigration: 2012 Report. Washington, DC: National Council of State Legislatures. <http://www. ncsl.org/issues-research/immig/state-laws-related-to-immigration-and-immigrants.aspx $>$ (accessed May 28, 2013).

Pendall, Rolf (2000). Local Land-Use Regulation and the Chain of Exclusion. Fournal of the American Planning Association, 66: 125-142.

Pendall, Rolf, Robert Puentes, and Jonathan Martin (2006). From Traditional to Reformed: A Review of Land Use Regulations in the Nation's 50 Largest Metropolitan Areas. Washington, DC: Brookings Institution Research Brief.

Piketty, Thomas and Emmanuel Saez (2003). Income Inequality in the United States, 1913-1998. Quarterly fournal of Economics, 158: 1-16.

Purnell, Thomas, William Idsardi, and John Baugh (1999). Perceptual and Phonetic Experiments on American English Dialect Identification. Fournal of Language and Social Psychology, 18: $10-30$.

Quillian, Lincoln (2006). New Approaches to Understanding Racial Prejudice and Discrimination. Annual Review of Sociology, 32: 299-328.

Quillian, Lincoln and Devah Pager (2001). Black Neighbors, Higher Crime? The Role of Racial Stereotypes in Evaluations of Neighborhood Crime. American Fournal of Sociology, 107(3): 717-767.

Quillian, Lincoln and Devah Pager (2010). Estimating Risk: Stereotype Amplification and the Perceived Risk of Criminal Victimization. Social Psychology Quarterly, 73(1): 79-104.

Reardon, Sean F. and Kendra Bischoff (2011). Income Inequality and Income Segregation. American fournal of Sociology, 116(4): 1092-1153.

Renuart, Elizabeth (2004). An Overview of the Predatory Lending Mortgage Lending Process. Housing Policy Debate, 15(3): 467-502.

Ross, Stephen L. and Margery A. Turner (2004). Other Things Being Equal: A Paired Testing Study of Discrimination in Mortgage Lending. Fournal of Urban Economics, 55: 278-297.

Rothwell, Jonathan (2011). Racial Enclaves and Density Zoning: The Institutionalized Segregation of Racial Minorities in the United States. American Law and Economics Review, 13(1): 290-358.

Rothwell, Jonathan and Douglas S. Massey (2009). The Effect of Density Zoning on Racial Segregation in U.S. Urban Areas. Urban Affairs Review, 44: 799-806.

Rothwell, Jonathan and Douglas S. Massey (2010). Density Zoning and Class Segregation in U.S. Metropolitan Areas. Social Science Quarterly, 91(5): 1123-1143.

Rugh, Jacob S. and Douglas S. Massey (2010). Racial Segregation and the American Foreclosure Crisis. American Sociological Review, 75(5): 629-651.

Sampson, Robert J. (2012). Great American City: Chicago and the Enduring Neighborbood Effect. Chicago, IL: University of Chicago Press.

Santa Ana, Otto (2002). Brown Tide Rising: Metaphors of Latinos in Contemporary American Public Discourse. Austin, TX: University of Texas Press.

Schuman, Howard, Charlotte Steeh, Lawrence D. Bobo, and Maria Krysan (1998). Racial Attitudes in America: Trends and Interpretations, Revised Edition. Cambridge, MA: Harvard University Press.

Smith, Robin and Michelle DeLair (1999). New Evidence from Lender Testing: Discrimination at the Pre-Application Stage. In Margery A. Turner and Felicity Skidmore (Eds.), Mortgage Lending Discrimination: A Review of Existing Evidence, pp. 23-41. Washington, DC: Urban Institute.

Squires, Gregory D. (1994). Capital and Communities in Black and White: The Intersections of Race, Class, and Uneven Development. Albany, NY: SUNY Press.

Squires, Gregory D. (2004). Why The Poor Pay More: How to Stop Predatory Lending. Westport, CT: Praeger/Greenwood Publishing Group.

Squires, Gregory D. and Jan Chadwick (2006). Linguistic Profiling: A Tradition of the Property Insurance Industry. Urban Affairs Review, 41(3): 400-415.

St. John, Craig (1996). Age, Racial Prejudice and Fear of Criminal Victimization in Public Settings. Sociological Focus, 29(1): 15-31.

Stephens-Davidowitz, Seth (2013). The Effects of Racial Animus on a Black Presidential Candidate: Using Google Search Data to Find What Surveys Miss. <http://www.people. fas.harvard.edu/ sstephen/papers/RacialAnimusAndVotingSethStephensDavidowitz.pdf> (accessed May 28, 2013). 
Sugrue, Thomas J. (1996). The Origins of the Urban Crisis: Race and Inequality in Postwar Detroit. Princeton, NJ: Princeton University Press.

Thernstrom, Stephen and Abigail Thernstrom (1997). America in Black and White: One Nation, Indivisible. New York: Simon and Schuster.

Turner, Margery A., Fred Freiberg, Eerin B. Godfrey, Carla Herbig, Diane K. Levy, and Robert E. Smith (2002). All Other Things Being Equal: A Paired Testing Study of Mortgage Lending Institution. Washington, DC: U.S. Department of Housing and Urban Development.

U.S. Federal Bureau of Investigation (2012). Uniform Crime Reporting Statistics. Washington, DC: U.S. Department of Justice. <http://www.ucrdatatool.gov/> (accessed May 28, 2013).

U.S. Immigration and Customs Enforcement (2012). Fact Sheet: Delegation of Immigration Authority Section $287(\mathrm{~g})$ Immigration and Nationality Act. Washington, DC: U.S. Immigration and Customs Enforcement. <http://www.ice.gov/news/library/factsheets/287g.htm> (accessed May 28, 2013).

U.S. Patent and Trademark Office (2012). Website of the U.S. Patent and Trademark Office. Washington, DC: U.S. Department of Commerce. <http://www.uspto.gov/about/stats/ index.jsp> (accessed May 28, 2013).

Wilkes, Rima and John Iceland (2004). Hypersegregation in the Twenty-First Century: An Update and Analysis. Demography, 4: 23-36.

Williams, Richard, Reynold Nesiba and Eileen Diaz McConnell (2005). The Changing Face of Inequality in Home Mortgage Lending. Social Problems, 52(2): 181-208.

Wolff, Edward N. (2010). Recent Trends in Household Wealth in the United States: Rising Debt and the Middle-Class Squeeze—an Update to 2007. Working Paper No. 589, Levy Economics Institute of Bard College. <http://www.levyinstitute.org/pubs/wp_589.pdf> (accessed May 28, 2013).

Ziegert Jonathan, C. and Paul J. Hanges (2005). Employment Discrimination: The Role of Implicit Attitudes, Motivation, and a Climate for Racial Bias. Fournal of Applied Psychology, 90: 553-562.

Zubrinsky, Camille L. and Lawrence D. Bobo (1996). Prismatic Metropolis: Race and Residential Segregation in the City of the Angels. Social Science Research, 25(2): 335-374.

\section{APPENDIX A}

Metropolitan Areas Included in Balanced Panel.

\begin{tabular}{ll}
\hline Abilene, TX MSA & Appleton, WI MSA \\
Akron, OH MSA & Asheville, NC MSA \\
Albany, GA MSA & Athens-Clarke County, GA MSA \\
Albany-Schenectady-Troy, NY MSA & Atlanta-Sandy Springs-Marietta, GA MSA \\
Albuquerque, NM MSA & Atlantic City-Hammonton, NJ MSA \\
Alexandria, LA MSA & Auburn-Opelika, AL MSA \\
Allentown-Bethlehem-Easton, PA-NJ & Augusta-Richmond County, GA-SC MSA \\
$\quad$ MSA & Austin-Round Rock-San Marcos, TX MSA \\
Altoona, PA MSA & Bakersfield-Delano, CA MSA \\
Amarillo, TX MSA & Baltimore-Towson, MD MSA \\
Ames, IA MSA & Bangor, ME MSA \\
Anchorage, AK MSA & Barnstable Town, MA MSA \\
Anderson, IN MSA & Baton Rouge, LA MSA \\
Anderson, SC MSA & Battle Creek, MI MSA \\
Ann Arbor, MI MSA & Bay City, MI MSA \\
Anniston-Oxford, AL MSA & Beaumont-Port Arthur, TX MSA
\end{tabular}

Continued 
Appendix A. (continued)

\begin{tabular}{|c|c|}
\hline Bellingham, WA MSA & Cleveland-Elyria-Mentor, OH MSA \\
\hline Bend, OR MSA & Coeur d'Alene, ID MSA \\
\hline Bethesda-Rockville-Frederick, MD MDIV & College Station-Bryan, TX MSA \\
\hline Billings, MT MSA & Colorado Springs, CO MSA \\
\hline Binghamton, NY MSA & Columbia, MO MSA \\
\hline Birmingham-Hoover, AL MSA & Columbia, SC MSA \\
\hline Bismarck, ND MSA & Columbus, GA-AL MSA \\
\hline Blacksburg-Christiansburg-Radford, & Columbus, IN MSA \\
\hline VA MSA & Columbus, OH MSA \\
\hline Bloomington, IN MSA & Corpus Christi, TX MSA \\
\hline Bloomington-Normal, IL MSA & Corvallis, OR MSA \\
\hline Boise City-Nampa, ID MSA & Crestview-Fort Walton Beach-Destin, \\
\hline Boston-Quincy, MA MDIV & FL MSA \\
\hline Boulder, CO MSA & Cumberland, MD-WV MSA \\
\hline Bowling Green, KY MSA & Dallas-Plano-Irving, TX MDIV \\
\hline Bremerton-Silverdale, WA MSA & Dalton, GA MSA \\
\hline Bridgeport-Stamford-Norwalk, CT & Danville, IL MSA \\
\hline MSA & Danville, VA MSA \\
\hline Brownsville-Harlingen, TX MSA & Davenport-Moline-Rock Island, IA-IL \\
\hline Brunswick, GA MSA & MSA \\
\hline Buffalo-Niagara Falls, NY MSA & Dayton, OH MSA \\
\hline Burlington, NC MSA & Decatur, AL MSA \\
\hline Burlington-South Burlington, VT MSA & Decatur, IL MSA \\
\hline $\begin{array}{l}\text { Cambridge-Newton-Framingham, MA } \\
\text { MDIV }\end{array}$ & $\begin{array}{l}\text { Deltona-Daytona Beach-Ormond Beach, } \\
\text { FL MSA }\end{array}$ \\
\hline Camden, NJ MDIV & Denver-Aurora-Broomfield, CO MSA \\
\hline Canton-Massillon, OH MSA & Des Moines-West Des Moines, IA MSA \\
\hline Cape Coral-Fort Myers, FL MSA & Detroit-Livonia-Dearborn, MI MDIV \\
\hline Cape Girardeau-Jackson, MO-IL MSA & Dothan, AL MSA \\
\hline Carson City, NV MSA & Dover, DE MSA \\
\hline Casper, WY MSA & Dubuque, IA MSA \\
\hline Cedar Rapids, IA MSA & Duluth, MN-WI MSA \\
\hline Champaign-Urbana, IL MSA & Durham-Chapel Hill, NC MSA \\
\hline Charleston, WV MSA & Eau Claire, WI MSA \\
\hline Charleston-North Charleston- & Edison-New Brunswick, NJ MDIV \\
\hline Summerville, SC MSA & El Centro, CA MSA \\
\hline Charlotte-Gastonia-Rock Hill, NC-SC & Elizabethtown, KY MSA \\
\hline MSA & Elkhart-Goshen, IN MSA \\
\hline Charlottesville, VA MSA & Elmira, NY MSA \\
\hline Chattanooga, TN-GA MSA & El Paso, TX MSA \\
\hline Cheyenne, WY MSA & Erie, PA MSA \\
\hline Chicago-Joliet-Naperville, IL MDIV & Eugene-Springfield, OR MSA \\
\hline Chico, CA MSA & Evansville, IN-KY MSA \\
\hline Cincinnati-Middletown, OH-KY-IN & Fairbanks, AK MSA \\
\hline MSA & Fargo, ND-MN MSA \\
\hline Clarksville, TN-KY MSA & Farmington, NM MSA \\
\hline Cleveland, TN MSA & Fayetteville, NC MSA \\
\hline
\end{tabular}


Appendix A. (continued)

\begin{tabular}{|c|c|}
\hline Fayetteville-Springdale-Rogers, AR-MO & Indianapolis-Carmel, IN MSA \\
\hline MSA & Iowa City, IA MSA \\
\hline Flagstaff, AZ MSA & Ithaca, NY MSA \\
\hline Flint, MI MSA & Jackson, MI MSA \\
\hline Florence, SC MSA & Jackson, MS MSA \\
\hline Florence-Muscle Shoals, AL MSA & Jackson, TN MSA \\
\hline Fond du Lac, WI MSA & Jacksonville, FL MSA \\
\hline Fort Collins-Loveland, CO MSA & Jacksonville, NC MSA \\
\hline Fort Lauderdale-Pompano Beach- & Janesville, WI MSA \\
\hline Deerfield Beach, FL MDIV & Jefferson City, MO MSA \\
\hline Fort Smith, AR-OK MSA & Johnson City, TN MSA \\
\hline Fort Wayne, IN MSA & Johnstown, PA MSA \\
\hline Fort Worth-Arlington, TX MDIV & Jonesboro, AR MSA \\
\hline Fresno, CA MSA & Joplin, MO MSA \\
\hline Gadsden, AL MSA & Kalamazoo-Portage, MI MSA \\
\hline Gainesville, FL MSA & Kankakee-Bradley, IL MSA \\
\hline Gainesville, GA MSA & Kansas City, MO-KS MSA \\
\hline Gary, IN MDIV & Kennewick-Pasco-Richland, WA MSA \\
\hline Glens Falls, NY MSA & Killeen-Temple-Fort Hood, TX MSA \\
\hline Goldsboro, NC MSA & Kingsport-Bristol-Bristol, TN-VA MSA \\
\hline Grand Forks, ND-MN MSA & Kingston, NY MSA \\
\hline Grand Junction, CO MSA & Knoxville, TN MSA \\
\hline Grand Rapids-Wyoming, MI MSA & Kokomo, IN MSA \\
\hline Great Falls, MT MSA & La Crosse, WI-MN MSA \\
\hline Greeley, CO MSA & Lafayette, IN MSA \\
\hline Green Bay, WI MSA & Lafayette, LA MSA \\
\hline Greensboro-High Point, NC MSA & Lake Charles, LA MSA \\
\hline Greenville, NC MSA & Lake County-Kenosha County, IL-WI \\
\hline Greenville-Mauldin-Easley, SC MSA & MDIV \\
\hline Gulfport-Biloxi, MS MSA & Lake Havasu City-Kingman, AZ MSA \\
\hline Hagerstown-Martinsburg, MD-WV & Lakeland-Winter Haven, FL MSA \\
\hline MSA & Lancaster, PA MSA \\
\hline Hanford-Corcoran, CA MSA & Lansing-East Lansing, MI MSA \\
\hline Harrisburg-Carlisle, PA MSA & Laredo, TX MSA \\
\hline Harrisonburg, VA MSA & Las Cruces, NM MSA \\
\hline $\begin{array}{l}\text { Hartford-West Hartford-East Hartford, } \\
\text { CT MSA }\end{array}$ & $\begin{array}{l}\text { Las Vegas-Paradise, NV MSA } \\
\text { Lawrence, KS MSA }\end{array}$ \\
\hline Hattiesburg, MS MSA & Lawton, OK MSA \\
\hline Hickory-Lenoir-Morganton, NC MSA & Lebanon, PA MSA \\
\hline Hinesville-Fort Stewart, GA MSA & Lewiston, ID-WA MSA \\
\hline Holland-Grand Haven, MI MSA & Lewiston-Auburn, ME MSA \\
\hline Honolulu, HI MSA & Lexington-Fayette, KY MSA \\
\hline Hot Springs, AR MSA & Lima, OH MSA \\
\hline Houma-Bayou Cane-Thibodaux, LA MSA & Lincoln, NE MSA \\
\hline Houston-Sugar Land-Baytown, TX MSA & Little Rock-North Little Rock-Conway, \\
\hline Huntington-Ashland, WV-KY-OH MSA & AR MSA \\
\hline Huntsville, AL MSA & Logan, UT-ID MSA \\
\hline Idaho Falls, ID MSA & Longview, TX MSA \\
\hline
\end{tabular}


Appendix A. (continued)

Longview, WA MSA

Los Angeles-Long Beach-Glendale, CA MDIV

Louisville/Jefferson County, KY-IN MSA

Lubbock, TX MSA

Lynchburg, VA MSA

Macon, GA MSA

Madera-Chowchilla, CA MSA

Madison, WI MSA

Manchester-Nashua, NH MSA

Manhattan, KS MSA

Mankato-North Mankato, MN MSA

Mansfield, OH MSA

McAllen-Edinburg-Mission, TX MSA

Medford, OR MSA

Memphis, TN-MS-AR MSA

Merced, CA MSA

Miami-Miami Beach-Kendall, FL MDIV

Michigan City-La Porte, IN MSA

Midland, TX MSA

Milwaukee-Waukesha-West Allis, WI MSA

Minneapolis-St. Paul-Bloomington, MN-WI MSA

Missoula, MT MSA

Mobile, AL MSA

Modesto, CA MSA

Monroe, LA MSA

Monroe, MI MSA

Montgomery, AL MSA

Morgantown, WV MSA

Morristown, TN MSA

Mount Vernon-Anacortes, WA MSA

Muncie, IN MSA

Muskegon-Norton Shores, MI MSA

Myrtle Beach-North Myrtle BeachConway, SC MSA

Napa, CA MSA

Naples-Marco Island, FL MSA

Nashville-Davidson-MurfreesboroFranklin, TN MSA

Nassau-Suffolk, NY MDIV

Newark-Union, NJ-PA MDIV

New Haven-Milford, CT MSA

New Orleans-Metairie-Kenner, LA MSA

New York-White Plains-Wayne, NY-NJ MDIV
Niles-Benton Harbor, MI MSA

North Port-Bradenton-Sarasota, FL MSA

Norwich-New London, CT MSA

Oakland-Fremont-Hayward, CA MDIV

Ocala, FL MSA

Ocean City, NJ MSA

Odessa, TX MSA

Ogden-Clearfield, UT MSA

Oklahoma City, OK MSA

Olympia, WA MSA

Omaha-Council Bluffs, NE-IA MSA

Orlando-Kissimmee-Sanford, FL MSA

Oshkosh-Neenah, WI MSA

Owensboro, KY MSA

Oxnard-Thousand Oaks-Ventura, CA MSA

Palm Bay-Melbourne-Titusville, FL MSA

Palm Coast, FL MSA

Panama City-Lynn Haven-Panama City Beach, FL MSA

Parkersburg-Marietta-Vienna, WV-OH MSA

Pascagoula, MS MSA

Peabody, MA MDIV

Pensacola-Ferry Pass-Brent, FL MSA

Peoria, IL MSA

Philadelphia, PA MDIV

Phoenix-Mesa-Glendale, AZ MSA

Pine Bluff, AR MSA

Pittsburgh, PA MSA

Pittsfield, MA MSA

Pocatello, ID MSA

Portland-South Portland-Biddeford, ME MSA

Portland-Vancouver-Hillsboro, OR-WA MSA

Port St. Lucie, FL MSA

Poughkeepsie-Newburgh-Middletown, NY MSA

Prescott, AZ MSA

Providence-New Bedford-Fall River, RI-MA MSA

Provo-Orem, UT MSA

Pueblo, CO MSA

Punta Gorda, FL MSA

Racine, WI MSA 
Appendix A. (continued)

\begin{tabular}{|c|c|}
\hline Raleigh-Cary, NC MSA & Sebastian-Vero Beach, FL MSA \\
\hline Rapid City, SD MSA & Sheboygan, WI MSA \\
\hline Reading, PA MSA & Sherman-Denison, TX MSA \\
\hline Redding, CA MSA & Shreveport-Bossier City, LA MSA \\
\hline Reno-Sparks, NV MSA & Sioux City, IA-NE-SD MSA \\
\hline Richmond, VA MSA & Sioux Falls, SD MSA \\
\hline Riverside-San Bernardino-Ontario, CA & South Bend-Mishawaka, IN-MI MSA \\
\hline MSA & Spartanburg, SC MSA \\
\hline Roanoke, VA MSA & Spokane, WA MSA \\
\hline Rochester, MN MSA & Springfield, IL MSA \\
\hline Rochester, NY MSA & Springfield, MA MSA \\
\hline Rockford, IL MSA & Springfield, MO MSA \\
\hline Rockingham County-Strafford County, & Springfield, OH MSA \\
\hline NH MDIV & State College, PA MSA \\
\hline Rocky Mount, NC MSA & Steubenville-Weirton, OH-WV MSA \\
\hline Rome, GA MSA & Stockton, CA MSA \\
\hline Sacramento-Arden-Arcade-Roseville, & Sumter, SC MSA \\
\hline CA MSA & Syracuse, NY MSA \\
\hline Saginaw-Saginaw Township North, MI & Tacoma, WA MDIV \\
\hline MSA & Tallahassee, FL MSA \\
\hline St. Cloud, MN MSA & Tampa-St. Petersburg-Clearwater, FL \\
\hline St. George, UT MSA & MSA \\
\hline St. Joseph, MO-KS MSA & Terre Haute, IN MSA \\
\hline St. Louis, MO-IL MSA & Texarkana, TX-Texarkana, AR MSA \\
\hline Salem, OR MSA & Toledo, OH MSA \\
\hline Salinas, CA MSA & Topeka, KS MSA \\
\hline Salisbury, MD MSA & Trenton-Ewing, NJ MSA \\
\hline Salt Lake City, UT MSA & Tucson, AZ MSA \\
\hline San Angelo, TX MSA & Tulsa, OK MSA \\
\hline San Antonio-New Braunfels, TX MSA & Tuscaloosa, AL MSA \\
\hline San Diego-Carlsbad-San Marcos, CA & Tyler, TX MSA \\
\hline MSA & Utica-Rome, NY MSA \\
\hline Sandusky, OH MSA & Valdosta, GA MSA \\
\hline San Francisco-San Mateo-Redwood & Vallejo-Fairfield, CA MSA \\
\hline City, CA MDIV & Victoria, TX MSA \\
\hline San Jose-Sunnyvale-Santa Clara, CA & Vineland-Millville-Bridgeton, NJ MSA \\
\hline MSA & Virginia Beach-Norfolk-Newport News, \\
\hline San Luis Obispo-Paso Robles, CA MSA & VA-NC MSA \\
\hline Santa Ana-Anaheim-Irvine, CA MDIV & Visalia-Porterville, CA MSA \\
\hline Santa Barbara-Santa Maria-Goleta, CA & Waco, TX MSA \\
\hline MSA & Warner Robins, GA MSA \\
\hline Santa Cruz-Watsonville, CA MSA & Warren-Troy-Farmington Hills, MI \\
\hline Santa Fe, NM MSA & MDIV \\
\hline Santa Rosa-Petaluma, CA MSA & Washington-Arlington-Alexandria, DC- \\
\hline Savannah, GA MSA & VA-MD-WV MDIV \\
\hline Scranton-Wilkes-Barre, PA MSA & Waterloo-Cedar Falls, IA MSA \\
\hline Seattle-Bellevue-Everett, WA MDIV & Wausau, WI MSA \\
\hline
\end{tabular}


Jacob S. Rugh and Douglas S. Massey

Appendix A. (continued)

Wenatchee-East Wenatchee, WA MSA

Winchester, VA-WV MSA

West Palm Beach-Boca Raton-Boynton

Winston-Salem, NC MSA

Beach, FL MDIV

Worcester, MA MSA

Wheeling, WV-OH MSA

Yakima, WA MSA

Wichita, KS MSA

Wichita Falls, TX MSA

Williamsport, PA MSA

York-Hanover, PA MSA

Youngstown-Warren-Boardman, OH-PA MSA

Wilmington, DE-MD-NJ MDIV

Yuba City, CA MSA

Wilmington, NC MSA

Yuma, AZ MSA 